\title{
The Study of Modern College Students' Employment Guidance Curriculum
}

\author{
Shaoxun Tang ${ }^{1, a}$ and Mingli Sun ${ }^{2, b}$ \\ ${ }^{1}$ Xincheng Street 2888, Jilin Agricultural University, Changchun, Jilin Province 130118, PR China \\ ${ }^{2}$ Changchun Architecture And Civilengeering College Changqing Road No. 15,Shuangyang District, \\ Changchun, Jilin Province 130699,PR China \\ a676537231@qq.com; b673533364@qq.com
}

Keywords: College students; Employment guidance course; Research

\begin{abstract}
It is very important to establish the employment guidance course of college students. On the one hand, it can improve the comprehensive ability of college students 'employment and can help them to achieve the goal of career planning. On the other hand, college students' employment guidance course of college students growth itself is an important part of education. National colleges and universities have carried out a variety of forms of college students employment guidance courses, but there are widespread teachers weak, single classroom teaching and many other issues. The college students' employment guidance course is different from other courses. It contains systematic knowledge and variety. The teaching form is flexible and how to improve the enthusiasm of students and improve the quality of teaching has become the core of curriculum inquiry.
\end{abstract}

\section{Introduction}

With the rapid development of national economy, our country has entered a transition stage of the fierce, the society and the enterprise and talent needs and expectations rising, coupled with the employment market saturation and talent diversification demand appeared obvious contradictions and conflicts, forcing colleges and universities in dealing with the problems of graduates and the development needs of the times with a derailment phenomenon. The employment problem of college graduates is increasing, adding a lot of burden and instability to the society and the school itself.[1]This kind of situation makes the work of college graduates from the original mechanism of maintaining the smooth employment of college students to serve the society, to actively help students in school during the establishment of the correct career development goals and achieve self-discovery positioning mechanism, and this mechanism is the carrier The introduction of the course will help students understand the relationship between self-education and self-development, self-cognition and cognitive world, and then improve the quality of individual employment and optimize the overall employment structure. The college students' employment guidance course becomes the relationship between the people's livelihood and the important works. Although the employment guidance course developed for many years, but in the development process, with the rapid development of the times and the economy, so that college students employment guidance courses exposed a lot of problems with the reality of disconnect. Whether from the classroom settings, writing materials and lesson plans to the case analysis and teaching model there are many places to be rectification. So, It is a pressing matter of the moment of employment guidance course to improve students actively, taking corresponding education mode according to the different objects of education and actively mobilize students' learning enthusiasm, and to improve the quality of employment guidance course for college students.

\section{The Role of Employment Guidance Courses in Colleges and Universities in China}

China's college students employment guidance course compared with the Western countries started late, the beginning is the rise in 2007, due to the State Ministry of Education Office on 
December 13, 2007 issued a "college students career development and employment guidance course teaching requirements" (No. 7 [2007] 7), it is clear that the employment guidance course runs through the entire training process of students from entry to graduation.[2]At that time, the employment guidance of colleges and universities was still in a primary stage. With the development of the past nine years, the number of college students' employment guidance courses and the number of relevant papers have been clearly broken. The employment guidance course of colleges and universities is also developing in the direction of whole process and professionalization. Most universities put a lot of manpower and material resources, and actively promote the rapid development of employment guidance course. In the curriculum structure optimization, it has increased the quality of employment promotion, career planning, employment guidance and innovation and entrepreneurship education module. In the subject construction, it combines sociology, economics, education and management and other disciplines to become a cross-disciplinary. In the curriculum concept, it combines knowledge transfer and skills training, teaching attitudes and ideas to be combined into a more practical comprehensive curriculum.[3]The purpose of the employment guidance course for college students is mainly in the following four aspects: (1) to enable college students to master the relevant policies and processes of graduation, to help them understand the various preferential policies that should be enjoyed during the employment process, Legal employment rights.(2) in the course of the course of education will be interspersed with some psychological knowledge, young students can learn to self-regulating psychological problems of the methods and techniques, and then resolve the employment process which appeared in various psychological problems.(3) so that young students can do a career development plan, through the practice of the students to understand the current situation of employment grim, for their future employment to seek direction.(4) through the employment guidance in the entrepreneurial education links, students can learn to start the basic process and basic methods to understand the laws and regulations and related policies of entrepreneurship, so as to stimulate students 'entrepreneurial awareness, improve students' social responsibility, Entrepreneurial ability to promote students' employment and all - round development.

Employment is not only related to the school's students, but also related to the growth of students into the problem. The employment guidance course of college students has become the necessary means to cultivate innovative talents, and it is also one of the important criteria to measure the success of university talents. Through the employment guidance course can actively help students to establish a correct world outlook, outlook on life, values, and guide them to establish the correct concept of employment, career and entrepreneurship to help them grow their health.

\section{The Problems in the Employment Guidance Course in Chinese Colleges and Universities}

First, the national colleges and universities a total of 2845, which includes the general institutions of higher education of 2553, adult institutions of higher learning of 292.Most of these schools carry out colorful teaching in the form of compulsory courses, examinations and elective courses. As a result of the teaching objectives, educational characteristics and teaching degree of the colleges and universities are very different, so far, colleges and universities for college students employment guidance course is not a unified outline and guiding materials, colleges and universities have their own Teachers to write the syllabus and design teaching links, and some schools even let the employment guidance of teachers free to play. Employment instructors themselves should go through the training of various levels of employment guidance courses, and through their own learning and practice, and then get the relevant qualifications of the staff composition, and some colleges and universities employment guidance teachers in the form of employment instructor level And the basic quality and lack of students can not provide high-quality employment guidance, at the same time, some colleges and universities do not attach importance to this course, neglect the curriculum evaluation system, so that career instructors can not concentrate on practical teaching, resulting in college students Not interested in this course, lost the real meaning of employment guidance. 
Second, at present, some colleges and universities in the teaching of employment guidance courses for college students, often overlooked the essence of employment guidance courses for college students, but also lost the essence of education, that is, individualized, pay attention to the overall quality of students training. In the course of teaching, the focus of the college students' employment guidance course is on the knowledge and the boring theory of writing, and some only remain in the unilateral skill transfer, how to use the skills to obtain a lot of information, how Conduct self-marketing and interview skills on the surface.

Thirdly, when setting up the syllabus of college students' employment guidance, this course is compared with other theoretical specialty, and the teaching of the theory course should be emphasized, and neglecting or not setting the teaching practice. At the same time in the number of courses, or take the traditional class teaching system, some of the classes are even reached about 300 people, this is not conducive to the quality of employment guidance course for college students, many of them still take the "cramming" classroom teaching mode, lack of interaction, it is difficult to mobilize the enthusiasm of the students.

Finally, the college students' employment guidance course in our country is very different from the employment guidance course of college students in western universities. Western university employment guidance courses are full, personalized and systematic education model, as Holland's personality type theory, like people and positions to match, and always pursue their peace and harmony between, and the employment Guidance as a goal for career planning.[5]In the course of teaching, we pay special attention to two points, the first is the teaching of individuality, while exploring individual differences, combined with practice and theory of active teaching, the pursuit of personalized development. Second, the combination of whole course education is lifelong occupation career. The employment guidance course of our university has not reached the life-long education level of the career guidance, but also does not combine the students' individual differences and the growth and achievement as the goal of individualized education, but the college students employment guidance course as graduation and employment skills enhancement tool Only to make the college students career guidance course lost meaning.

\section{The Construction of Employment Guidance Courses in Colleges and Universities in China}

Hina's college students employment guidance course teaching model is too old, a single teaching method, according to can not adapt to the actual needs of society. Our curriculum is designed to enable college students to master the skills of job search, in the process of job search to establish the correct concept of employment, adjust the employment mentality and employment expectations, and a single teaching simply can not stimulate the students' passion.[6]It is very important to strengthen the case in the teaching process. The boring theory is not to motivate students to learn. The case teaching is to let the students through the simulation of the cases appear in the case, so that students can be integrated into the classroom through the discussion and exchange the practice of teaching mode. As the college students employment guidance course itself is neglected from the practical curriculum, so many of the knowledge points in the classroom can be combined with the actual case, to strengthen the classroom interaction between teachers and students, and then stimulate the students' imagination, understanding and creativity. Teachers in the preparation of the case, we must combine the actual case, especially in the school or students are familiar with the students who occurred in the case, so close to the distance between the students, to be more interested in this course. After the case is explained, it should always focus on specific knowledge points and questions, and actively organize students to discuss and discuss, so that each student can become a spokesman, through classroom communication, to enable students to recognize their own right Form of employment, such teaching can be meaningful.

To actively collect the authoritative data and strengthen the analysis and collation of real-time data. In the course of employment guidance for college students, there will be a lot of comprehensive data on national policy and employment information. As a qualified teacher, the knowledge must fully grasp. In the classroom which can also be positive to the students to answer, and as a solution is the process of learning, first of all their own learning process, followed by the 
process of answering, to allow other students on a social phenomenon and information have a certain understanding of The future of their own employment foreshadowed. Only fresh and vivid cases and real-time information, in order to break the traditional classroom boring style of teaching.

A variety of media forms can be integrated into the classroom teaching. In the college students employment guidance course, faced with the needs of students, their attention is not the same. For the students looking for work, the most concerned about the employment skills, one of the most important is the establishment of the production, teachers can use the network media to show students resume production methods and skills, but also can collect some students Their own resume, through the classroom real evaluation of the pros and cons of students resume, so that students real and effective grasp of production skills.[8]For the graduate students, teachers should collect the professional students in recent years, the proportion of graduate students in different schools and the professional characteristics of different schools, with the image of the icon for the students to do the show, while guiding students how to review postgraduate courses, how to choose the school Or outside the professional skills and methods of graduate students. For the students who face civil servants will not only teach them how to interview, but also help them to analyze the proportion of civil servants in recent years and related policies. The classroom through the visual, auditory full stimulation to stimulate college students for this course of love, and thus enhance the overall effect of teaching.

Visiting practice is an important part of teaching, which is conducive to students' absorption and understanding of classroom knowledge. Actively organize students to participate in school recruitment and recruitment, corporate visits and simulated recruitment, so that students participate in the comb after the formation of summary reports and papers, so that their understanding and theory to combine, and then grasp the most cutting forward dynamic changes, broad Vision, growth of employment skills and skills, from the fundamental to receive inspiration, and thus enhance the initiative and consciousness of learning. At the same time, this link also helps to make up for the lack of curriculum teaching process.[9]

Strengthen the school-enterprise communication construction, so that students find self-social value. In the course of student internships, teachers can carry out continuous docking mode. To classify the acAfter summarizing the analysis, can be used as the main case of the classroom depth of summary and classroom reports tual situation of internship students. The employment guidance teaching of perseverance, adhere to the multi material information absorbing method, to treat students.[10]Teachers are the cornerstones of college students into the social stage, only words and deeds and regular practice experience, will let the students in practice test the truth, understand the truth, understand the social system and interpersonal principles. Everyone who is inferior to society has its own social value, but how to correctly understand how to properly release its own social value is part of the inevitable teaching in the process of imitation into society. Then strengthen the school-enterprise cooperation, the establishment of a solid communication bridge will make the campus and the enterprise better convergence, is the bag of students detours, more confidence.

Implementation of "people-oriented" targeted experimental teaching. For each type of student groups to be employed to specify a precise, practical teaching program, so that every student really benefit from the classroom.[11]Different groups of students have different career positioning, teachers should be closely combined with the different characteristics of different students on a regular basis for sub-group consultation and discussion. And through personal resume, personal statements and other material analysis to develop employment interview matters, research preparation work or study abroad and other related materials. In the pre-school can be different from the different aspects of the students to guide, such as college students innovation and entrepreneurship competition, social practice, professional visits and so on. Through a wide range of channels to lead students, so that students have a clear life planning. "People-oriented" but also always pay attention to students in different periods of ideological dynamics, according to the characteristics of interest to set the classroom content, so that the classroom itself is full of vitality, so that students themselves have power. 
The development and construction of the employment guidance course of college students is a huge and complicated project, mainly from the elements of classroom teaching, the teachers' own comprehensive quality, the students' sense of identity and the degree of concern to the school students' employment guidance course. The future of this inquiry in the need to focus on two aspects, first, college students employment guidance courses and China's current social reality of the degree of integration. Second, the design of college students' employment guidance course practice teaching and the verification in practice. Only to actively mobilize the students' participation and consciousness in order to truly play the real role of college students employment guidance.

\section{References}

[1] L.F Fei, College students employment guidance course teaching and practice [J]. Journal of Changchun Normal University, 2014, (9).

[2] L.J Cheng, C Fan and X Gao, Research on the curriculum system of career education in colleges and universities based on practical exploration. Education development research, 2012 (3): 69-73.

[3] X.L Liu, College students career planning and employment guidance micro-class development and design research [J]. Management Manager, 2016, (22): 382-383.

[4] H.Jin, X.H Li and J.L Li, Study on the construction of college students employment guidance course teaching model [J]. Times Literature, 2015, (9).

[5] X.H Sun, College students employment guidance concept and practice mode of thinking [J]. Fujian Forum (Humanities and Social Sciences Edition), 2015, (9).

[6] B Li, Undergraduate education concept under the guidance of college students employment

[7] X Yang, College employment guidance management system construction problems [D]. Hebei University, 2016.

[8] F.F Gao, Study on the Innovation of College Students' Employment Guidance Course from the Perspective of the Transformation and Development of Colleges and Universities [J]. School Party Building and Ideological Education, 2016, (09): 83-84.

[9] L Hong, P Zhang, Deepening the reform of college students employment guidance curriculum thinking [J]. Science and Technology Guide (mid-term), 2015, (10): 173-174.

[10] N.S Ma, Employment guidance of college students employment ability from the perspective of inquiry teaching [J]. Journal of Shanxi Coal Mining Administrators College, 2015, 158 (03): $155-156$.

[11] S.F Chen, On the employment guidance course teaching reform of college students thinking [J]. Intelligence, 2015, (12): 232. 